\section{Kort og greit nok om akutt kirurgi}

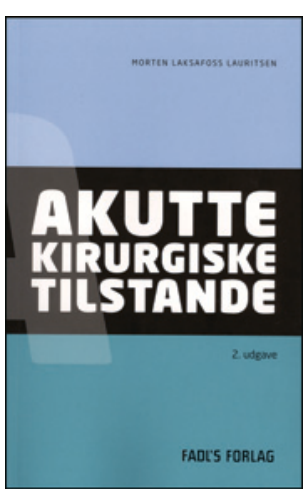

Morten Laksafoss Lauritsen Akutte kirurgiske tilstande

2. utg. 298 s, tab, ill. København: FADL's

Forlag, 2014. Pris DKK 380

ISBN 978-87-7749-711-7

Denne publikasjonen henvender seg til medisinstudenter, turnusleger og leger i spesialisering innen kirurgi som er tidlig i sin karriere. Forfatteren sier i forordet at han selv manglet en håndbok i akutt kirurgi da han var relativt ny i faget, og han prøver her å bøte på denne mangelen. Han har derfor vektlagt de vanligste kirurgiske tilstander og prosedyrer som man møter på vakt i kirurgiske avdelinger ved skandinaviske sykehus.

Dette er en liten håndbok, med mykt omslag og tynne ark, som kan få plass i en frakkelomme. Den består av 20 kapitler med en kort omtale av de vanligste kirurgiske lidelsene. Det finnes også en del bilder. Boken starter med den kirurgiske journalen, som etterfølges av anamnese og symptomer, initial behandling, blodprøver og blodprodukter, radiologi, endoskopiske undersøkelser, væskebehandling, smerte- og kvalmestillende behandling, operasjonspasienten, akutt abdomen hos barn, gastrointestinal blødning, icterus, fremmedlegemer i fordøyelseskanal og luftveier, akutte abdominalkirurgiske tilstander, akutte urologiske sykdommer, akutte karkirurgiske sykdommer, akutte thoraxkirurgiske tilstander, komplikasjoner og reinnleggelser, og traumatologi, og til slutt et kapittel om kliniske prosedyrer. Der omtales innleggelse av blærekateter, arteriepunksjon, gynekologisk undersøkelse, nedlegging av gastroduodenal/ventrikkelsonde, perifer venetilgang og innleggelse av pleuradren. Innleggelse av suprapubiskateter er derimot ikke med. Det er viet en del plass til vanlige røntgenbilder, og CT-bilder illustrerer blant annet fri luft og ileus.

Totalt sett er boken kort, oversiktelig og inneholder det viktigste man må kjenne til hos akuttkirurgiske pasienter. I tillegg er prisen overkommelig. Den kan derfor anbefales til målgruppen. Men for de som har smarttelefon, er den nok overflødig.

\section{Kenneth Thorsen}

Lege i spesialisering, Kirurgisk avdeling

Stavanger universitetssjukehus

\section{Stressmestring for dummies}

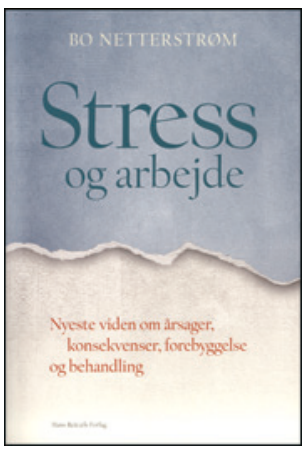

\section{Bo Netterstrøm \\ Stress og arbejde}

Nyeste viden om årsager, konsekvenser. forebyggelse og behandling. 275 s, tab, ill. København: Hans Reitzels Forlag, 2014. Pris DKK 300

ISBN 978-87-412-5794-5

Forfatteren er nestor innenfor dansk arbeidsmedisin og stressforskning, og denne utgivelsen er en oppdatert videreføring av hans to tidligere «bestselgere» $(1,2)$. Til tross for at Netterstrøm tilhører bestefargenerasjonen (født 1947), er han meget godt oppdatert, også med hensyn til nye sosiale medier. Et av hans smarte grep er at han avslutter boken med en fiktiv pressekonferanse, der han svarer på spørsmål han ofte får fra journalister, for eksempel dette: «Det at vi hele tiden må forholde oss til smarttelefon, e-post, sms-er, Facebook og mange andre nye fenomener, fører ikke det til et enormt stress?» Hans svar, som også er typisk for tekstens litt tilbakelente stil, er at det er først når man lar seg styre av disse mediene, at man blir stresset.

Som antydet i overskriften for denne anmeldelsen er dette en bok som virkelig følger Søren Kierkegaards råd om «at man, naar det i Sandhed skal lykkes En at føre et Menneske hen til et bestemt Sted, først og fremmest maa passe paa at finde ham der, hvor han er, og begynde der». Netterstrøm begynner med å fortelle realistiske historier om John som skal opp til eksamen, håndballtreneren Kim under en kamp, IT-konsulent Thomas som aldri har nok tid, og Jytte med sin overinvolvering. Her vil nok mange lesere nikke gjenkjennende på egne eller andres vegne. Forfatteren har dermed presentert et godt utgangspunkt for å lære mer om og forstå bedre stress og stressrespons.

I kapitlet om behandling blir vi også kjent med 47 år gamle Hanne som har en rekke stressrelaterte symptomer, og som gjennom kapitlet prøver en rekke forskjellige teknikker og tiltak i håp om å bli mindre stresset, fra nye joggesko til mindfulness. I det etterfølgende kapitlet, om stressforebygging på arbeidsplassen, beskrives et trettitalls mulige stressorer, og for hver eneste en finnes det et avsnitt som heter «Løsninger». Begge disse kapitlene er etter min mening pedagogiske fulltreffere.

Litt overraskende er det derfor at kapittel 2 om stressfysiologi, og til dels kapittel 3 om årsaker, er noe vanskelig tilgjengelige for en vanlig leser. Her kreves en god porsjon naturvitenskapelig forkunnskap for å kunne følge med. Men en «dummy»-leser kan godt hoppe over disse kapitlene og likevel ha stort utbytte av boken, noe forfatteren kanskje kunne ha foreslått i forordet.

Til slutt finner vi selvsagt en «test-deg-selv»-stresstest.

Olaf Gjerløw Aasland

Instituttsjef, Legeforskningsinstituttet

Litteratur

Netterstrøm B. Stress på arbejdspladsen. Årsager, forebyggelse og håndtering København: Hans Reitzels Forlag. 2003.

2. Netterstrøm B. Stresshåndtering. København: Hans Reitzels Forlag, 2008. 